JOURNAL OF

HORTICULTURAL

SCIENCES
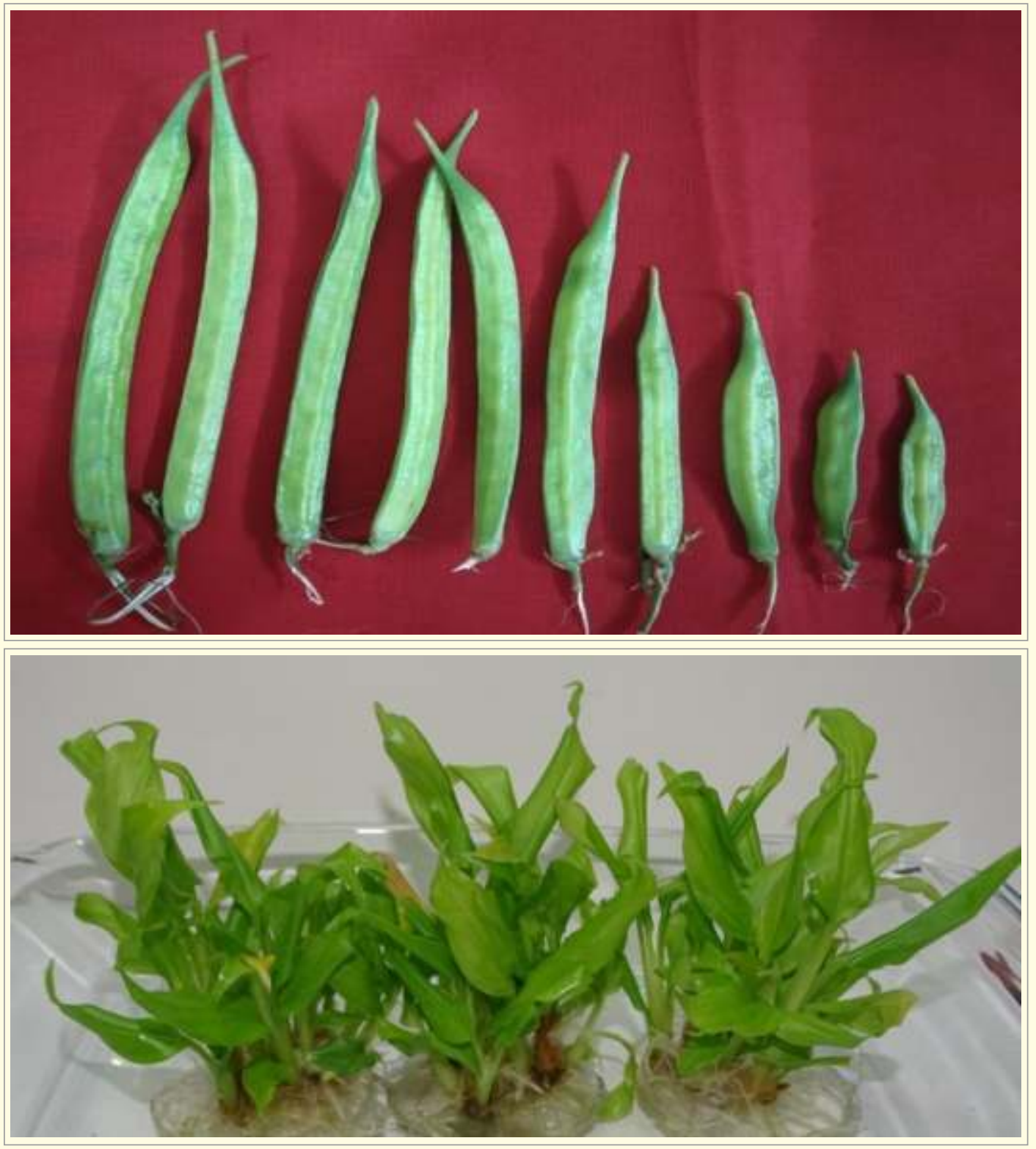

Society for Promotion of Horticulture

ICAR - Indian Institute of Horticultural Research, Bengaluru - 560089 


\section{JOURNAL OF HORTICULTURAL SCIENCES}

\section{ONTENTS}

\section{In this Issue}

\section{Review}

Moringa (Moringa oleifera L.): An underutilized and traditionally valued

tree holding remarkable potential

Jattan M., Kumari N., Raj Kumar, Kumar A., Rani B., Phogat D.S.,

Kumar, S. and Kumar, P.

\section{Original Research in Papers}

Characterization and evaluation of mountain sweet thorn

(Flacourtia montana J. Grah) collections

Tripathi P.C., Ganeshan S., Radhika V. and Shetti D.L.

Optimization of methodology for the extraction of polyphenolic compounds

with antioxidant potential and á-glucosidase inhibitory activity from jamun

(Syzygium cumini L.) seeds

Arivalagan M., Priyanka D.R. and Rekha A.

Genetic variability studies in amaranthus (Amaranthus spp.)

Agadi A.H., Kolakar S., Lakshmana D., Nadukeri S. and Hanumanthappa M.

Morpho-physiological parameters associated with chlorosis resistance to

iron deficiency and their effect on yield and related attributes in potato

(Solanum tuberosum L.)

Challam C., Dutt S., Sharma J., Raveendran M. and Sudhakar D.

Responses of different Okra (Abelmoschus esculentus) cultivars to water

deficit conditions

Ayub Q., Khan S.M., Hussain I., Naveed K., Ali S., Mehmood A., Khan M.J., Haq N.U., Shehzad Q.

Induced variability for yield and its attributing traits in cluster bean

[Cyamopsis tetragonoloba (L. ) Taub] through gamma irradiation

Lavanya H.N., Mishra S., Sood M., Aghora T.S., Anjanappa M., Rao V.K. and Reddy A.B.

In vitro multiplication protocol for Curcuma mangga : Studies on carbon,

Waman A.A., Bohra P., Karthika Devi R. and Pixy J. 
Effect of fungicide and essential oils amended wax coating on quality and shelf life of sweet orange (Citrus sinensis Osbeck)

Bhandari M., Bhandari N. and Dhital M.

Post-harvest quality and quantification of betalains, phenolic compounds and antioxidant activity in fruits of three cultivars of prickly pear

(Opuntia ficus-indica L. Mill)

Gonzalez F.P.H., Saucedo V.C., Guerra R.D., Suarez E.J., Soto H.R.M. Lopez J.A.,

Garcia C.E. and Hernandez R.G.

Soil microbial community dynamics as influenced by integrated nutrient management practices in sweet basil (Ocimum basilicum L.) cultivation Baraa AL-Mansour and D. Kalaivanan

Effect of spectral manipulation and seasonal variations on cut foliage production and quality of Philodendron (Philodendron 'Xanadu')

Sujatha A. Nair, Laxman R.H. and Sangama

\section{Short Communications}

Studies on mutagenic sensitivity of seeds of pummelo (Citrus maxima Merr.)

Sankaran M., Kalaivanan D. and Sunil Gowda D.C.

Isolation and characterization of microsatellite markers from

Garcinia indica and cross species amplification

Ravishankar K.V., Vasudeva R., Hemanth B., Nischita P., Sthapit B.R.,

Parthasarathy V.A. and Rao V.R. 


\title{
Induced variability for yield and its attributing traits in cluster bean [Cyamopsis tetragonoloba (L. ) Taub] through gamma irradiation
}

\author{
Lavanya H.N. ${ }^{1}$, Mishra S. ${ }^{2 *}$, Sood M. ${ }^{1}$, Aghora T.S. ${ }^{2}$, Anjanappa M. ${ }^{1}$, Rao V.K. ${ }^{2}$ and Reddy A.B. ${ }^{1}$ \\ ${ }^{1}$ College of Horticulture, University of Horticultural Sciences, Bengaluru 560 065, Karnataka, India \\ ${ }^{2}$ ICAR- Indian Institute of Horticultural Research, Bengaluru 560 089, Karnataka India \\ *Corresponding author e-mail : smaranika.mishra@icar.gov.in,mishrasmaranika@gmail.com
}

\begin{abstract}
Gamma ray is an effective mutagen which creates useful variability for crop like cluster bean where the natural variation is very meagre and creation of variability by conventional methods is cumbersome. In the present study, cluster bean cv. Pusa Navbahar was treated with different level of gamma rays from $50 \mathrm{~Gy}$ to $600 \mathrm{~Gy}$ with $50 \mathrm{~Gy}$ interval and obtained $M_{2}$ population was subjected to variability estimation for yield and its attributing traits in augmented block design. The variance between the control and the mutants was found to be significant for plant height, number of pods per cluster, number of pods per plant, pod length, pod width, pulp to seed ratio. For these traits, PCV ranged from 14.28 per cent (pod width) to 31.99 per cent (pulp to seed ratio) whereas, GCV ranged from 10.10 per cent (pod width) to $\mathbf{2 4 . 1 6}$ per cent (pulp to seed ratio). The heritability in broad sense ranged from 50 per cent (pod width) to 79.99 per cent (Plant height). Genetic advance expressed as percentage over mean ranged from 2.06 per cent (pod width) to 222.44 per cent (plant height). The traits like plant height, pod length, pod width, pulp to seed ratio showed sufficient variability due to induced mutation. All these traits showed medium to high heritability and high genetic advance hence selection for these traits will be effective.
\end{abstract}

Key words : Cluster bean, Gamma irradiation, Mutation and Variability

\section{INTRODUCTION}

Cluster bean (Cyamopsis tetragonoloba L. Taub) is an underutilized vegetable from the family Fabaceae. But its nutritional value, hardiness and ease in growing makes it a suitable crop for future. Presently, it is being grown widely in north-western states of India for guar gum production which has a high industrial value. Whereas, in south India, it is grown mainly for vegetable purpose. In Karnataka, it is grown yearround in northern districts like Dharwad, Belagavi, Vijayapura and Haveri. Despite its nutritional importance, the area under vegetable cluster bean cultivation is very small due to non-availability of suitable variety. For developing an improved variety, genetic variability for desired traits is a pre-requisite. Cluster bean is a self-pollinated crop with a very narrow genetic base and creation of variation through manual hybridization is further difficult and not economical, owing to small flowers. Looking into this limitation, efforts were made to create variability in cluster bean using induced mutations and selecting the elite genotypes.
Mutations are the heritable changes which alter the phenotype of an organism. It is created by changes in the sequence of base pairs in the genes or changes in chromosome structure and number. The process of mutagenesis alters the biological organization of an individual. It is desirable to select and screen the mutants in $\mathrm{M}_{2}$ generation as recessive mutation will express at this stage. The use of mutagens is a valuable supplemental strategy to plant breeding in cluster bean (Yadav et al., 2014; Akhtar et al., 2015). It creates variability both in terms of qualitative and quantitative traits which are needed for selection. Mutations are very helpful particularly when it is aimed to improve one or two easily identifiable characters in a well-adapted variety. The present investigation was carried out to generate variability in one of the widely cultivated commercial variety 'Pusa Navbahar' which has reached a plateau in terms of yield and attributing traits. 


\section{MATERIAL AND METHODS}

The present study was conducted using cluster bean variety Pusa Navbahar which was treated with 12 different doses of gamma rays from 50 Gy to $600 \mathrm{~Gy}$ with 50Gy interval at the Gamma irradiation facility available at ICAR- Indian Institute of Horticultural Research, Bengaluru. The $M_{1}$ seeds were planted in a replicated trial in field and all the survived $M_{1}$ plants (605 lines) were harvested separately to form the $M_{2}$ generation seeds. These $M_{2}$ seeds were sown in plant to progeny rows along with parent Pusa Navbahar and 3 other check varieties (MDU 1, Swarna and Sonali) in an augmented block design. The whole plot was divided into 5 blocks and in each block 122 lines were sown except for block 1 where 121 lines were sown. Seeds were sown on raised beds of length 5 $\mathrm{m}$ and width $1 \mathrm{~m}$ with a spacing $30 \times 15 \mathrm{~cm}$ between rows and plants (December 2018 to April 2019). All the recommended package of practices were followed and from each treatment, 10 plants were randomly selected for recording the data on different quantitative characters in $\mathrm{M}_{2}$ generation. Similarly, 10 plants were picked up from the checks for comparative assessment. Observations were recorded on days to 50 per cent flowering, number of clusters per plant, number of pods per cluster, total number of pods per plant, pod length $(\mathrm{cm})$, pod width $(\mathrm{cm})$, 10 pod weight $(\mathrm{g})$, pulp to seed ratio, yield per plant $(\mathrm{g})$ and plant height $(\mathrm{cm})$. Based on these observations the parameters of variability like GCV, PCV, heritability $\left(\mathrm{h}^{2}\right)$ (Allard, 1960) and genetic advance (Johnson et al.,1955) were calculated to identify the traits based on which selections can be made. OPSTAT software was used for the estimation of above parameters.

\section{RESULTS AND DISCUSSION}

The analysis of variance (Table 1) revealed significant variation for most of the traits studied. Mutants exhibited significant variation for plant height, days to 50 per cent flowering, pod length, pod width and pulp to seed ratio while it was non-significant for number of clusters per plant, number of pods per cluster, number of pods per plant, pod yield and pulp to seed ratio. The variance between the control and the mutants was found to be significant for plant height, number of pods per cluster, number of pods per plant, pod length, pod width, pulp to seed ratio and for only these selected traits, the estimates of variability such as genotypic coefficient of variation (GCV), phenotypic coefficient of variation (PCV), heritability in broad sense $\left(h^{2}\right)$, genetic advance (GA) was calculated along with mean, range, standard error of mean, critical difference and coefficient of variation (Table 2). Graphical representation of GCV, $\mathrm{PCV}, \mathrm{h}^{2}$ and $\mathrm{GA}$ is presented in Fig 1 and 2 respectively.

Table 1: Analysis of variance for yield and its attributing traits in $M_{2}$ generation

\begin{tabular}{|l|c|c|c|c|c|}
\hline \multirow{2}{*}{ Source of variation } & \multicolumn{4}{|c|}{ Mean sum of squares } \\
\cline { 2 - 6 } & $\begin{array}{c}\text { Entries over } \\
\text { sample }\end{array}$ & Control & Mutants & $\begin{array}{c}\text { Control Vs. } \\
\text { mutants }\end{array}$ & Error \\
\hline df & 609 & 3 & 605 & 1 & 12 \\
\hline Plant height (cm) & 375.81 & 1170.21 & $145.76^{*}$ & $128106.58^{*}$ & 29.16 \\
\hline Number of clusters per plant & 1.61 & 2.91 & $1.49^{\mathrm{NS}}$ & $0.98^{\mathrm{NS}}$ & 1.26 \\
\hline Number of pods per cluster & 0.28 & 4.17 & $0.22^{\mathrm{NS}}$ & $26.92^{*}$ & 0.58 \\
\hline Number of pods per plant & 41.07 & 41.73 & $36.93^{\mathrm{NS}}$ & $1560.23^{*}$ & 75.02 \\
\hline Days to 50\% flowering & 5.73 & 46.32 & $4.36^{*}$ & $5.12^{\mathrm{NS}}$ & 1.11 \\
\hline Pod length (cm) & 2.39 & 11.77 & $2.00^{*}$ & $144.66^{*}$ & 0.49 \\
\hline Pod width (cm) & 0.02 & 0.06 & $0.02^{*}$ & $0.05^{*}$ & 0.01 \\
\hline Pod yield (g) & 418.66 & 7553.45 & $258.47^{\mathrm{NS}}$ & $69623.26^{*}$ & 617.31 \\
\hline 10 pod weight (g) & 24.16 & 17.63 & $18.87^{\mathrm{NS}}$ & $40.41^{\mathrm{NS}}$ & 9.78 \\
\hline Pulp to seed ratio & 18.79 & 2.85 & $18.37^{*}$ & $68.29^{*}$ & 7.89 \\
\hline Powdery mildew & 69.27 & 144.77 & $67.17^{*}$ & $594.69^{*}$ & 7.08 \\
\hline
\end{tabular}

* denotes significant at $\mathrm{P} \leq 0.05$

${ }^{N S}$ denotes Non-significant at $\mathrm{P} \leq 0.05$ 


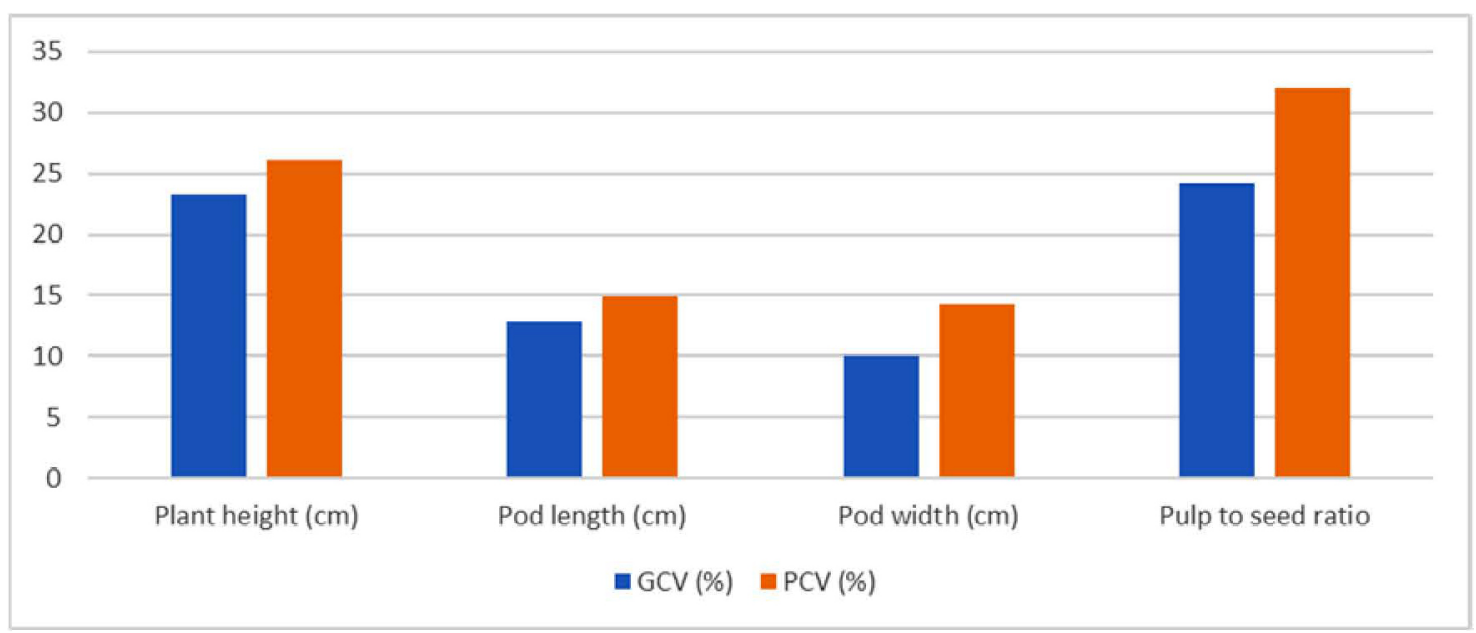

Fig. 1: Genotypic and phenotypic coefficient of variation for yield attributing traits in $M_{2}$ generation

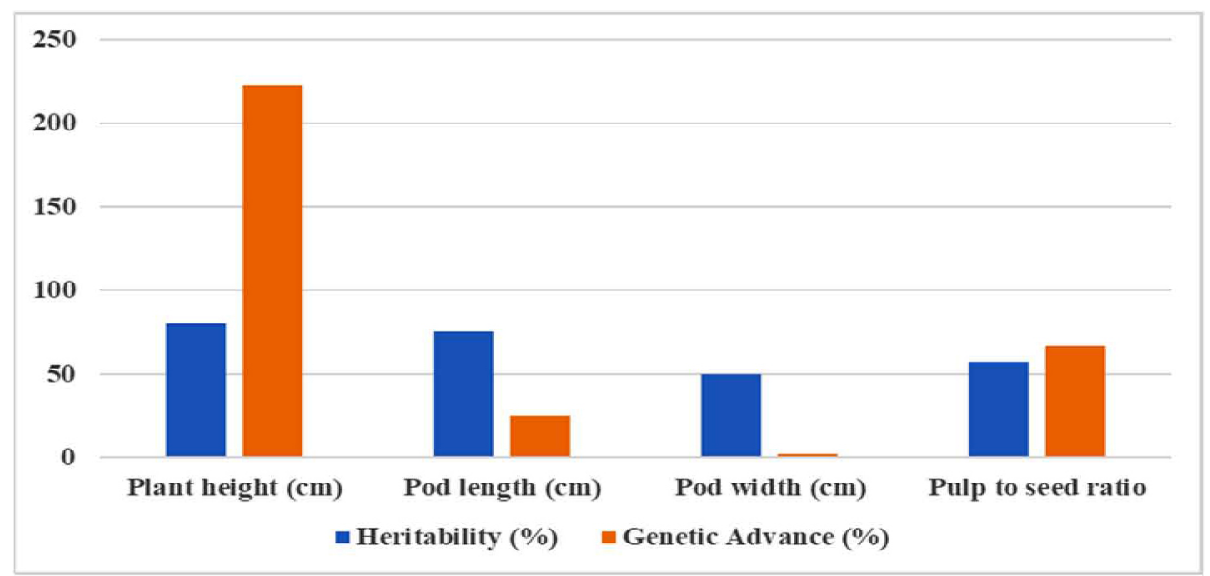

Fig. 2: Heritability and genetic advance for yield attributing traits in $M_{2}$ generation

Table 2: Parameters of variability for yield and its significantly attributing traits in $\mathrm{M}_{2}$ generation

\begin{tabular}{|l|c|c|c|c|c|c|c|c|c|}
\hline Traits & Mean & Range & $\begin{array}{c}\text { SE(m) } \\
\pm\end{array}$ & $\begin{array}{c}\text { CD } \\
\mathbf{5} \%\end{array}$ & $\begin{array}{c}\text { CV } \\
(\%)\end{array}$ & $\begin{array}{c}\text { GCV } \\
(\%)\end{array}$ & $\begin{array}{c}\text { PCV } \\
(\%)\end{array}$ & $\begin{array}{c}\mathbf{h}^{2} \\
(\%)\end{array}$ & $\begin{array}{c}\text { GA } \\
(\%)\end{array}$ \\
\hline Plant height (cm) & 46.25 & $20.00-142.00$ & 6.39 & 13.92 & 11.67 & 23.35 & 26.10 & 79.99 & 222.44 \\
\hline Number of pods per cluster & 4.84 & $3.97-8.20$ & 0.90 & 1.95 & 15.7 & NS & NS & NS & NS \\
\hline Number of pods per plant & 32.53 & $21.67-64.67$ & 10.25 & 22.24 & 26.63 & NS & NS & NS & NS \\
\hline Pod length (cm) & 9.51 & $5.60-15.20$ & 0.83 & 1.81 & 7.39 & 12.92 & 14.87 & 75.50 & 25.31 \\
\hline Pod width (cm) & 0.99 & $0.80-1.20$ & 0.07 & 0.15 & 5.74 & 10.10 & 14.28 & 50.00 & 2.06 \\
\hline Pod yield/plant (g) & 61.67 & $28.86-190.80$ & 29.40 & 63.80 & 40.29 & NS & NS & NS & NS \\
\hline Pulp to seed ratio & 13.40 & $5.03-28.70$ & 3.32 & 7.24 & 20.97 & 24.16 & 31.99 & 57.05 & 66.69 \\
\hline
\end{tabular}

$\mathrm{SE}(\mathrm{m})$ - tandard error of mean

$\mathrm{CD}$ - Critical difference

$\mathrm{CV}$ - Coefficient of variation

GCV - Genotypic coefficient of variation
PCV - Phenotypic coefficient of variation

$\mathrm{h}^{2}-$ Broad sense heritability

GA - Genetic advance as per cent of mean 
For all the traits, PCV showed higher values compared to GCV but small difference between these values indicated less environmental influence. PCV ranged from 31.99 per cent (pulp to seed ratio) to 14.28 per cent (pod width), whereas GCV ranged from 24.16 per cent (pulp to seed ratio) to 10.10 per cent (pod width). Traits like plant height and pulp to seed ratio showed moderate PCV and GCV. According to Khan and Wani (2006) moderate to high phenotypic and genotypic variance in the quantitative traits in all the mutagenic treatments indicates better chances for selection to be successful. However, coefficient of variation alone is not an effective indicator, to determine the amount of variation and it also depends on the heritability and genetic advance of the trait. The heritability in broad sense ranged from 50 per cent (pod width) to 79.99 per cent (Plant height). Genetic advance expressed as percentage over mean ranged from 2.06 per cent (pod width) to 222.44 per cent (plant height). According to Singh (2001), if heritability of a character is very high ( $>50 \%)$, selection for such traits could be fairly easy. Mishra et al., 2020 has also reported in cluster bean that characters like number of pods per plant, pod length, pod weight, plant height, number of clusters per plant, pods per cluster showed high coefficient of variations and high heritability with high genetic gain indicating their suitability for effective selection. This is because there would be a close correspondence between the genotype and the phenotype due to the

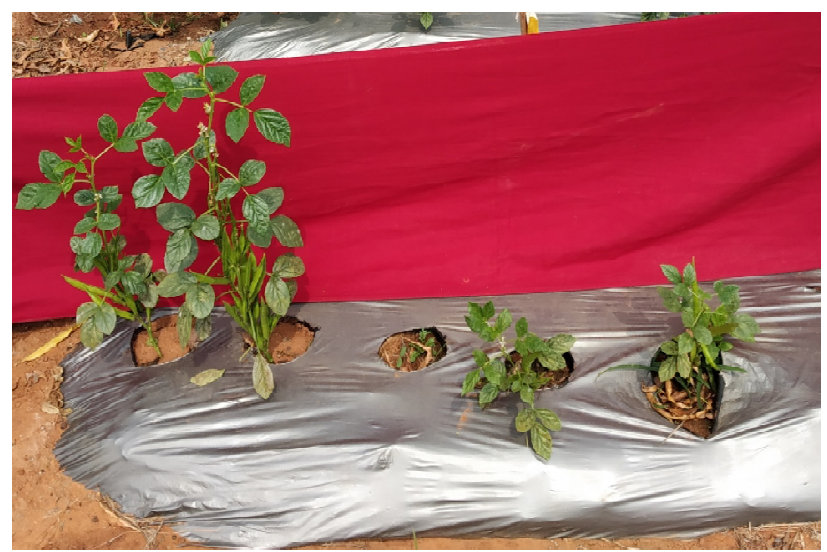

Fig. 3: Variation in plant height obtained in $\mathrm{M}_{2}$ generation (dwarf mutants) relatively small contribution of the environment to the phenotype. Johnson et al. (1955) suggested that high heritability combined with high genetic advance as per cent mean is indicative of additive gene action and selection based on these parameters would be more reliable. In this study, plant height (Fig. 3) showed moderate GCV but high PCV and high heritability along with very high genetic advance indicating the additive gene. action, thus making it responsive to selection. Likewise, pulp to seed ratio showed moderate GCV but high PCV, moderate heritability but high genetic advance indicating the dominance of additive gene action favouring selection for improvement of this trait.

Whereas, traits like number of clusters per plant, number of pods per plant, ten pod weight and yield per plant revealed non-significant differences among mutants indicating selection for this trait from the mutant population will be ineffective because of predominance of environmental effect. For days to 50 per cent flowering, variation was found significant between mutants but nonsignificant over checks that means mutants are on par with the checks or they are of late maturing types which is not the objective of the present study. The variation created through mutation for pod length (Fig. 4) was found significant between the mutants and also over checks. It showed low GCV and PCV but high heritability coupled with moderate genetic advance. Selection would be effective for this trait because of higher heritability and moderate genetic advance due to additive gene

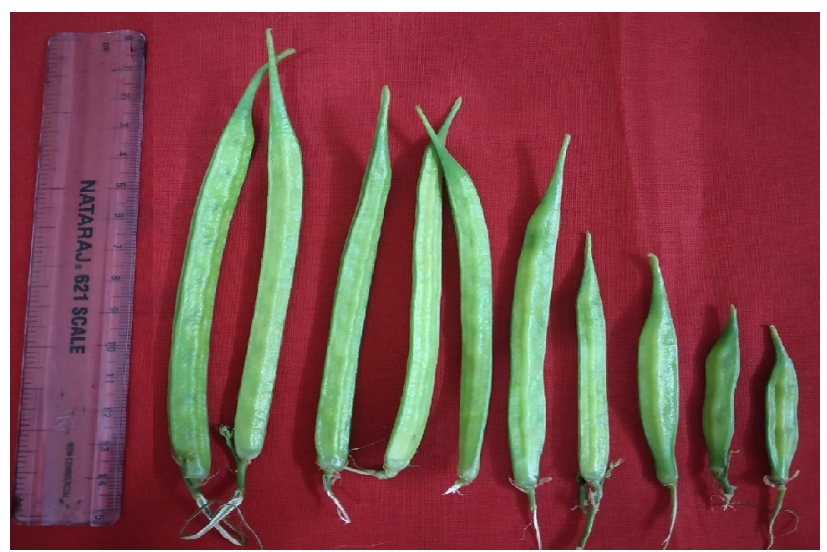

Fig. 4: Variation in pod length obtained through mutation in $\mathrm{M}_{2}$ generation 
action in its background. However, pod width of mutants exhibited low GCV, PCV with moderate heritability along with very low genetic advance. This may be due to higher environmental influence and non-additive gene action. Therefore, selection followed by few generations of selfing would help in breaking the non-additive gene action. It can be concluded here that sufficient variability could be created for traits like plant height, pod length, pod width and pulp to seed ratio through induced mutation in cluster bean. Further improvement of these traits through selection is possibly result in a superior mutant variety/line in cluster bean.

\section{ACKNOWLEDGEMENT}

The authors express their gratitude to Director, ICARIIHR for extending all necessary facilities by granting permission to carry out the research work at ICARIIHR, Bangalore and providing the gamma chamber facility for the mutation study.

\section{REFERENCES}

Akhtar, L.H., Minhas, R., Bukhari, M.S. and Shah, S.A. 2015. Genetic analysis of some quantitative traits in Cyamopsis tetragonoloba (L) Taub. Journal of Environmental and Agricultural Sciences 4: 48-51.

Allard, R.W. (1960) Principles of Plant Breeding. John Willey and Sons Inc., New York.

Johnson, H.W., Robinson, H.F. and Comstock, R.E. 1955. Genotypic and phenotypic correlations in soybean and their implication in selection. Agronomy Journal 47: 477-483.

Khan, S and Wani, M.R. 2006. Estimates of genetic variability in mutated populations and the scope of selection for yield attributes in mung bean (Vigna radiata L. Wilczek). Egyptian Journal of Biology 8: 1-6.
Mishra, S., Aghora, T.S. and Senthil Kumar, M. 2020. Genetic variability, character association and path analysis for quantitative traits to breed vegetable type cluster bean (Cyamopsis tetragonoloba). Indian Journal of Agricultural Sciences 90 (3): 537-540.

Singh, B.D. 2001. Plant breeding: principles and methods. pp. 896. Kalyani Publishers, New Delhi.

Yadav, S.L., Singh, V.V., Ramakrishna, K and Kumar, M. 2014. Evaluation of promising $M_{3}$ progenies in respect to growth and yield attributes in guar [Cyamopsis tetragonoloba (L) Taub]. Environment and Ecology 32(4): 1622-1627.

Received on 9.12.2020, Revised on 14.04.2021, Accepted on 16.04.2021 